ppi $201502 Z U 4645$

Esta publicación científica en formato digital es continuidad de la revista impresa ISSN-Versión Impresa 0798-1406 / ISSN-Versión on line 2542-3185Depósito legal pp $197402 Z$ U34

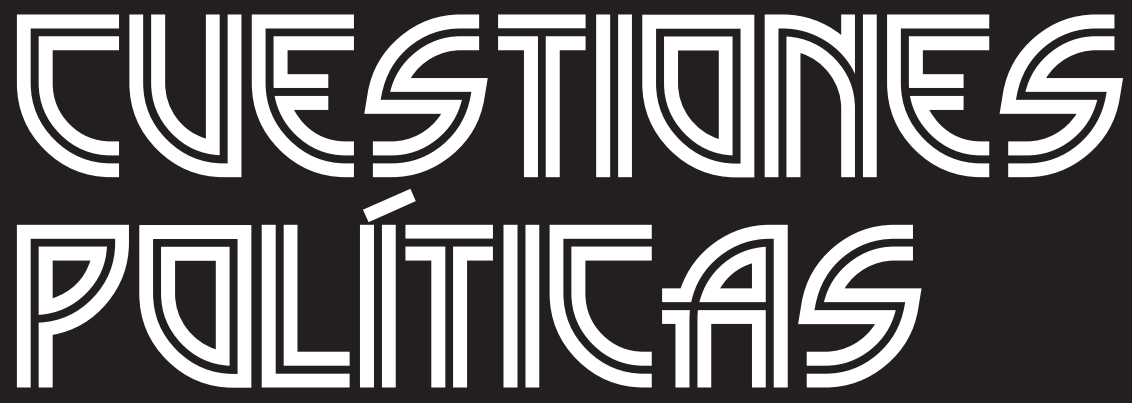

Instituto de Estudios Políticos y Derecho Público "Dr. Humberto J. La Roche" de la Facultad de Ciencias Jurídicas y Políticas de la Universidad del Zulia Maracaibo, Venezuela
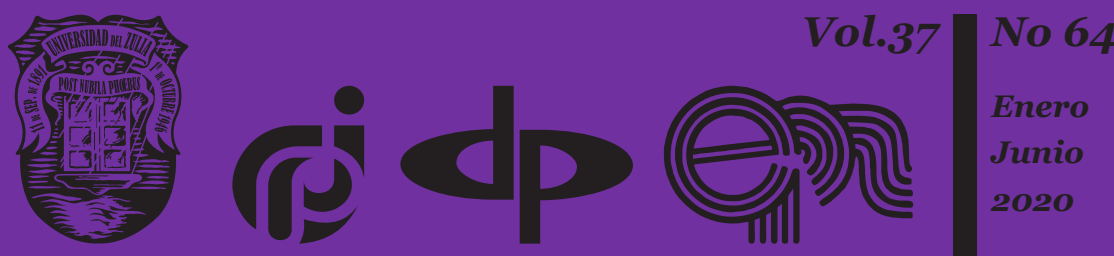


\title{
Development Of Creativity As The Basis Of Innovative Activity Of A University Teacher
}

\author{
E.V. Yakovleva * \\ A.V. Denisenko ** \\ E.F. Shaleeva $* * *$ \\ S.I. Artemyeva $* * * *$ \\ N.P. Rodinova $* * * * *$ \\ V.M. Ostroukhov $* * * * *$ \\ M.S. Kalney
}

\section{Abstract}

There is an active search for policies and methods to improve the quality of education in the vocational studies system, with all that it represents. Pedagogical work is a special type of highly skilled mental work that has a creative character and is characterized by a high degree of tension. The work of a teacher is a conscious and appropriate activity for the training, education and development of students and of society as a whole. The objective of the research is to discuss the development of creativity based on the innovative activity of teachers. It is concluded that the teacher has a main role as an agent in the formation of professional knowledge among students. The real problems of psychology and pedagogy in the modern education system are the definition of the professional requirements for the personality of a modern teacher and the psycho-diagnosis of the level of his professional qualities. However, these questions take on a political meaning because they concern the human development of a society and must therefore also be politically debated.

* Doctor of Philology, Associate Professor, Peoples' Friendship University of Russia. Email: rector. office@rudn.ru.

** Candidate of Philological Sciences, Associate Professor, Peoples' Friendship University of Russia. Email: rector.office@rudn.ru.

*** Senior Teacher, Peoples' Friendship University of Russia. Email: rector.office@rudn.ru.

****Candidate of Historical Sciences, Associate Professor, K.G.Razumovsky Moscow State University of Technologies and Management (the First Cossack University). Email: rektorat@mgutm.ru.

***** Doctor of Economical Sciences, Professor, K.G.Razumovsky Moscow State University of Technologies and Management (the First Cossack University). Email: rektorat@mgutm.ru.

****** Candidate of Economical Sciences, Associate Professor, K.G.Razumovsky Moscow State University of Technologies and Management (the First Cossack University). Email: rektorat@mgutm. ru.

******* Candidate of Philosophy Sciences, Associate Professor, Sociology and Politology Department of National Research University of Electronic Technology. Email: netadm@miee.ru.

Recibido: 14/01/2020. Aceptado: 30/03/20. 
Keywords: creativity and critical thinking; innovative teacher activity; imitation of professional training methods; creative work; education and politics.

\section{Desarrollo de la creatividad como base de la actividad innovadora de un profesor universitario}

\section{Resumen}

Hay una búsqueda activa de politicas y métodos para mejorar la calidad de la educación en el sistema de estudios vocacionales, con todo lo que ello representa. El trabajo pedagógico es un tipo especial de trabajo mental altamente calificado que tiene un carácter creativo y se caracteriza por un alto grado de tensión. El trabajo de un maestro es una actividad consciente y apropiada para la capacitación, educación y desarrollo de los estudiantes y asi como de la sociedad en su conjunto. El objetivo de la investigación consiste en discutir el desarrollo de la creatividad con base a la actividad innovadora del profesorado. Se concluye que el maestro tiene un papel principal como agente en la formación del conocimiento profesional entre los estudiantes. Los problemas reales de la psicología y la pedagogía en el sistema de educación moderna son la definición de los requisitos profesionales para la personalidad de un maestro moderno y el psico-diagnóstico del nivel de sus cualidades profesionales. No obstante, estas cuestiones adquiere un sentido político porque atañen al desarrollo humano de una sociedad y deben ser, por lo tanto, debatidas también políticamente.

Palabras clave: creatividad y pensamiento crítico; actividad innovadora del profesor; imitación de métodos de formación profesional; trabajo creativo; educación y política.

\section{Introduction}

The person who organizes and implements the educational process is a teacher. We can say this: a teacher (teacher, tutor, mentor, master) is a person who has taken special training and is professionally engaged in 
the teaching activities. Almost all people are engaged in unprofessional pedagogical activity, but only teachers know what to do, where it is needed and how it should be done, know how to act in accordance with pedagogical laws, bear the responsibility for the quality performance of their professional duty in the established manner (Bagaeva, 1991). The work of the teacher is independent creative work, which in it's turn is the organized part of the labor on a society level. Its features are due to the specifics of the educational process. The pedagogical process embodies the acute, specific dialectics of the subjective and objective. On the one hand, a strictly objective analysis of pedagogical phenomena is supposed here, on the other hand, this analysis is subjective by the personality of the teacher as a carrier of a certain creative individuality, which, in turn, is objectified by the conditions of influence under the same psychological and pedagogical situation and other things being equal for different teachers. Thus, this subjective factor is of great importance in the creative process of the teacher (Shchurkova, 1998).

The object of pedagogical work is also specific - not a lifeless product of nature, but a person with individual qualities, with a unique character and temperament, under the influence of many factors and people who transform it.

The teacher does not create alone, but in a team of people who think alike. The outstanding teacher and educator V. A. Sukhomlinsky wrote about this: "All the anxiety, all the sorrows and all the triumph of our wokr lies in the fact that there are several sculptors. This is the family and personality of the teacher, and the children's team, and the book, and completely unforeseen sculptors, say acquaintances, who the children get to know on the street and with whom they make friends. If all these forces acted as a well-coordinated orchestra, how easily people would be created! " (Bogoyavlenskaya, 1981).

\section{Literature Review}

According to V. M. Roginsky, a tendency to teach, as a rule, manifests itself at a fairly mature age. University teachers usually achieve expertise and excellence after working for 10-15 years, because teachers are not born, but become in the process of gaining experience and continuous improvement (Roginsky, 1990). A.V. Morozov and D.V. Chernilevsky argue that the activity of a teacher in the context of subject and scientific work, in the context of pedagogical communication is inevitably associated with the occurrence of problem situations and the need to resolve them, which implies the presence of a component of the process in pedagogical activity decision making. The ability to correctly make decisions in various 
situations determines the ability of a teacher to perform their professional functions (Sergeeva, 2015). The decision-making process is a component of any activity, including pedagogical, and has a personal coloring, expressed in the individual characteristics of the subject, to identify which, they use the study of the motivational sphere of the person using various questionnaires (for example, A. Edwards's Questionnaire of Personal Preferences) and methodology, involving the analysis of individual behavior in the process of solving practical situations.

In the A. Edwards questionnaire, subjects are asked to compare two statements that characterize it to a greater or lesser extent. According to the frequencies of his personal preferences, indices of motivational tendencies are calculated: achievement motivation, love of order, autonomy, selfperception, dominance, guilt, persistence in self-achievement, tolerance for the new. It is also practiced to analyze the behavior of the subject in the process of solving problem situations in the form of model decision-making situations with a set of alternative options in order to identify personal behavioral characteristics. An analysis of the results of recent sociopsychological studies revealed in the average personality profile of a higher school teacher the severity of motivational tendencies such as "tolerance for the new" (cognitive interest), "love of order", "persistence in achieving goals "(endurance) and" autonomy "(independence) (Khozyainov, 1998). A.V. Morozov and D.V. Chernilevsky conclude that high indicators in the first three parameters indicate the severity of such needs for teachers, which are associated with a tendency to learn new things, broaden their horizons, to experiment, readiness to changes in the conditions of activity, with the desire and ability to organize and maintain their affairs in order, to plan their activities, with the presence of a sufficiently high degree of endurance in achieving their own goals. In the professional activity of a teacher, these qualities, and hence the motivational trends associated with them, are significant.

The revealed expressions of motivational tendencies indicate wellinterpreted relationships between the indicators of the scales and the form of activity of the subjects, that is, we can talk about the conformity of test indicators to such an external criterion as their belonging to this professional group. Low indicators on the "autonomy" scale characterize the teacher as dependent in his actions and decisions on situations, professional and ethical standards, requirements, and other factors (Badakhova, 2017; Borisova et al, 2018; Borovikova, 2017; Gadzaov \& Dzerzhinskaya, 2018; Gasanova et al, 2017; Gnatyuk \& Pekert, 2018; Kuznetsov et al, 2018). The weak expression of this motivational tendency can probably be explained by qualities such as flexibility and comfort due to the strict criteria of ethical standards in pedagogical communication and the peculiarities of the hierarchical relations of the teaching staff as a whole, inherent in teachers. 
A comparison of the results of recent studies with previously published data on the features of the motivational structure of another domestic sample revealed the difference between the groups of teachers on such a scale (motivational trend) as "autonomy". On other scales, from the point of view of the content of maintaining one's affairs in order, the demonstration of endurance in self-attainment and "permeability" for the new one, a general pattern of expression of the corresponding motivational tendencies is observed: "love of order", "persistence in achieving goals", "tolerance to the new "for higher school teachers as a whole, that is, one can make a statement about the personal characteristics of teachers who characterize these motivational trends as professionally manifested, and from the teaching point of view activities, they look prognostically significant (Stolyarenko, 2015). According to the classification of E. A. Klimov, the teacher's profession refers to the type of professions "person-person", therefore personality traits that determine the interaction of a person with a person are represented in this profession in many ways and widely.

\section{Proposed Methodology}

V. Levy characterizes the variety of creative manifestations of a teacher and shows that a teacher, depending on the situation, can be an observer, supervisor, mentor, researcher, doctor, comrade, critic, and so on. Answering the question "The genius of communication, what is he like?", He identifies the following qualities (Bukhvalov, 1993).

Plus interest. Great curiosity, colossal greed for people, hence the increased attention, and subtle observation, and excellent memory for everything relating to other people ...

Minus anxiety. With all his liveliness, mobility, this man is extremely calm. The centers of fear are, as it were, underdeveloped: carelessness is quite common. It is remarkable, however, that in at least 90 cases out of 100 this nonchalance turns out to be wisdom ...

Plus feedback. You still take a look, and he has already looked three times and understands your view as an old acquaintance ... High sensitivity to changes ... The ability to easily, quickly adapt, excellent mobility of the psyche is an innate property, but also amenable to training. Associated qualities: dexterity, tact, resourcefulness, wit, artistry.

Plus artistry. A great variety of gestures and intonations; excellent storyteller, imitator and mime. A taste for detail, for juicy details. The inexhaustible gambling excitement is not a card player, but more of a child eager to live different lives. 
Plus aggressiveness. Given the general background of benevolence and complacency, the genius of communication is not devoid of aggressiveness, which is rare, but accurate ...

Plus optimism. Optimism as a conviction, as a life attitude and optimism as a state, a feeling of the joy of being - the above are different things, although they are interconnected.

Minus bias (prejudice). Lack of prejudice. Joint immunity to any other opinions about a person, as well as titles and titles that block the essence.

Plus sympathy. And a number of pedagogical principles that guide a creatively working teacher: first principle - understand; the second principle - create a favorable atmosphere, the third principle - do not humiliate; fourth principle - exalt.

The process of professional development of a teacher begins with the student bench of a pedagogical university. A.A. Soldatova, in her research, argues that if changes are introduced into the educational and cognitive process of a pedagogical university that creates conditions for the creative expression of subjects of education, it will contribute to the formation of relevant personal qualities and properties of students that are important in the implementation of innovative activities. These conditions are (Narkevich \& Narkevich, 2018): a change in the function of a lecture from information to a coordinating one, which allows one to master the methods of cognitive activity; directing the independent work of students, orienting them towards the solution of pedagogical problems; organization of a dialogue interaction in the systems teacher - student, student - student. A.A. Soldatova considers the self-expressing personality of the teacher as the core of any pedagogical innovation, which the success of the innovation will ultimately depend on. The analysis of the structure of innovative pedagogical activity, the study of the requirements for the teacher that are relevant at the present stage of the development of pedagogical science made it possible for A. A. Soldatova to identify a set of significant requirements for the teacher-innovator, among which (Pionova, 2002): the formation of the motivational sphere, the teacher's desire for self-development, and self-actualization in the professional activities; the formation of qualities that characterize a creative person (resourcefulness, desire for discoveries, openness, emphasizing one's "I", tolerance, etc.); experience in the implementation of known methods of pedagogical activity; innovative style of thinking, determined by the formation of the methodological culture of the teacher; development of reflexive processes.

The distinguished qualities and personality traits of the teacher of innovative activity allowed A. A. Soldatova to determine creative selfexpression as the dominant factor in preparing for innovative activity, ensuring their formation, to identify the main directions of the organization 
E.V. Yakovleva, A.V. Denisenko, E.F. Shaleeva, S.I. Artemyeva, N.P. Rodinova, V.M. Ostroukhov y M.S. Kalney

of the educational-cognitive process with a focus on the creative selfexpression of subjects of education (Kan-Kalik, 1981).

Creativeself-expression seems to betherealmechanism that characterizes the teacher's ability to go beyond simple execution, to rise above a specific activity, to prevent the transformation of activity into functional behavior. Creative self-expression is not just a representation of oneself for others, it is a remake of the person himself, his individual consciousness, his ability to know, to act. A person expressing his "I" is turned to culture, he is capable of transformative activity, of self-development. Creative self-expression is always a search in oneself of the spiritual, essential, it is a path to oneself (Zagvyazinsky, 1987).

Creative self-expression acts as a means of becoming ready for innovation and performs the following functions in the educational process (Kan-Kalik, 1990):

- determines the formation of the motivational sphere of the teacher of innovative activity, promotes self-development, self-actualization of the future teacher;

- contributes to the formation of qualities that characterize a creative person: ability to collaborate, know one self, desire for discoveries, flexibility, originality, openness, etc .;

- is the result and an external manifestation of reflection, ensuring the productivity of professional activity;

- the creative potential of the subject of education is realized through acts of creative self-expression.

A. A. According to Soldat's conditional conditions, in the case of creative self-cultivation, preparations are made for innovative activities. Conditions reflect the process of learning and co-learning components of the learning process and name the following features (Shtykova, 2001):

- the use of methods and forms of organization of training are aimed at creative self-expression of students (in changing the characteristics of the leadership of students' independent work, which in the context of ideas of creative self-expression is holistic, is set as a problem, in revising the system of control over the level of formation of knowledge and skills of the students, in including students in dialogue interaction during seminars);

- restructuring the educational content, allowing future teachers to master not only a variety of information, but also how to obtain it (in changing the main function of lectures from information to coordinating, in enriching the student's methodological culture, in complementing the educational content with knowledge about 
the essence of innovative activity and the skills necessary for its implementation).

Practice confirms the close relationship between the processes of creative expression and readiness for innovative pedagogical activity. Manifesting itself as one of the main means of preparing for the introduction of pedagogical innovations, self-expression also acts as a condition for the success of its implementation (Yakovleva, 1991).

\section{Result Analysis}

In order for innovations introduced into the pedagogical process to be effective, they should be managed by "manager - innovator" (V. P. Kvasha, A. M. Moiseev, A. M. Novikov, M. M. Potashnik). It requires skills to organize research activities, scientific expertise and counseling in an educational institution, to create an atmosphere of interest, recognition and exchange of opinions around the innovator (V. I. Zvereva, A. E. Kapto, A. V. Lorensov). The following situation has developed in educational institutions: on the one hand, there is a variety of innovations, the need to organize them (the planning of innovations is meant by organization, as well as the implementation and interpretation of the results), and on the other hand - the uncertainty of the content of activities and requirements for the teacher organizing innovative activities (Ponomarev, 1976).

According to L. A. Shtykova, the effective organization of innovative activity in an educational institution is ensured provided that: the professional suitability of the teacher organizing the innovative activity is determined; creating an environment for innovation and assessing its effectiveness in the mode of pedagogical monitoring; recertification of teachers organizing innovative activities (Shtykova, 2001).

L. A. Shtykova offers a model of professional activity of the organizer of innovation in an educational institution, a developed algorithm and criteria for the effectiveness of the organization of innovative activity (table 1). 
E.V. Yakovleva, A.V. Denisenko, E.F. Shaleeva, S.I. Artemyeva, N.P. Rodinova, V.M. Ostroukhov y M.S. Kalney

\section{Table 1. Model of professional activity of an innovator in an educational institution}

\begin{tabular}{|c|c|l|}
\hline № & Model component & \multicolumn{1}{|c|}{ Characteristics } \\
\hline 1. & The nature of innovation & $\begin{array}{l}\text { Due to their diversity, reflects the } \\
\text { interests and needs of the leaders of } \\
\text { educational institutions, teachers, } \\
\text { students and their parents. }\end{array}$ \\
\hline 2. & $\begin{array}{l}\text { Requires an organization implemented } \\
\text { by the organizer of innovation. The } \\
\text { content of his activity is determined } \\
\text { using expert methods that can provide } \\
\text { a qualified opinion on the functional } \\
\text { responsibilities of the organizer of } \\
\text { innovation of interested participants in } \\
\text { the educational process. }\end{array}$ \\
\hline 3. & $\begin{array}{l}\text { Activities of the innovation } \\
\text { organizer }\end{array}$ & $\begin{array}{l}\text { Are carried out at three hierarchical } \\
\text { levels of management }\end{array}$ \\
\hline 4. & $\begin{array}{l}\text { Organes the following: } \\
\text { 1) collection, processing, } \\
\text { systematization, accumulation and use } \\
\text { of information on innovations; } \\
\text { 2) resource justification and } \\
\text { determination of the mechanism } \\
\text { for the practical implementation of } \\
\text { innovative processes; } \\
\text { 3) development of projects, programs, } \\
\text { regulations for the implementation } \\
\text { of innovative processes and their } \\
\text { evaluation according to certain criteria; } \\
\text { 4) development of a control system. }\end{array}$ \\
\hline 5. & $\begin{array}{l}\text { activity } \\
\text { Innovation Organizer Activity } \\
\text { Model }\end{array}$ & $\begin{array}{l}\text { A system with a functional structural } \\
\text { organization. This is expressed in the } \\
\text { primacy of the functions given to the } \\
\text { system. }\end{array}$ \\
\hline
\end{tabular}

(Own elaboration, 2020).

Various structural units and mechanisms are created in order to enable the organization and management of innovation in an educational institution. For example, in the Tver State Industrial and Economic College A.N. Konyaev created a laboratory of innovative technologies (three teachers and six students), whose task is to introduce modern educational technologies into the educational process to prepare a competitive college 
graduate in demand on the labor market (Sergeeva \& Trubakova, 2017). The task is realized by creating organizational and pedagogical conditions for the teacher for practical methodological work in the implementation of simulation teaching methods. The following were developed for this purpose: information bank; system of expert services; various ways of counseling and coordination among educators. One of the ways of scientific and methodological assistance in the college is the "School of Pedagogical Excellence", where the teacher, the master of industrial training of the highest category, translates the accumulated experience of studying and introducing new technologies into practice. The basic principles of methodological work in college - comfort for each teacher.

The training method "Educational Firm" was developed and experimentally tested at the college (Sergeeva \& Trubakova, 2017); The effectiveness of the application of simulation teaching methods on the example of experimental training is estimated.

A comparative analysis of the use of simulation teaching methods by $\mathrm{M}$. G. Sergeeva revealed their advantages and disadvantages. For example, the analysis of specific situations involves the collective adoption of a managerial decision, which stimulates the development of behavioral qualities, including sociability. In our study, this method was applied to conduct management classes on the topic "Making Management Decisions", which carried out inter subject communications in marketing, organization of industries, paperwork, and accounting. The solution of situational production tasks in the classes on "Personnel Management" on the topic "Ways to attract staff to work. Sources and methods of recruitment "contributes to the formation of professional skills necessary for solving specific management situations, systematization of theoretical knowledge gained, develops discussion skills and the ability to manage and obey.

The use of exercises - actions according to the instructions is especially effective in the classes on the discipline "Automated Systems for Processing Economic Information", since the objectives of the classes on this discipline include: developing skills and abilities to work with Excel spreadsheets and Access databases; fixing applications of the basic techniques of working with spreadsheets; database creation; fostering accuracy, independence, etc. When creating an automated workplace for an accountant, classes were conducted by simulating professional activities using simulators using universal computer accounting programs 1C: Bookkeeping and Info-Accountant, the purpose of which was to develop skills to create an economic workbook operations, necessary accounting books, input of initial balances, details of the enterprise, skills to configure the type of journal and commercial operations, etc. The case method allows the teacher to apply an individual approach to each student, take into account his needs and build students' self-management skills, the ability to work with information, 
E.V. Yakovleva, A.V. Denisenko, E.F. Shaleeva, S.I. Artemyeva, N.P. Rodinova, V.M. Ostroukhov y M.S. Kalney

206

Development Of Creativity As The Basis Of Innovative Activity Of A University Teacher

thereby developing the student's strengths. A striking example of a creative search for improving pedagogical mastery is the application of the moderation method, which consists in establishing rules and monitoring them when working with the audience when solving the problem "What qualities a modern teacher should have".

Based on the results of the study, we developed a model for the formation of pedagogical skills of a teacher in the process of his activity (Fig. 1). Particular attention in the model is paid to such elements of the creative process as the criteria for pedagogical excellence and the conditions of practical pedagogical activity, realized through pedagogical and psychological technologies that are mastered by the teacher.

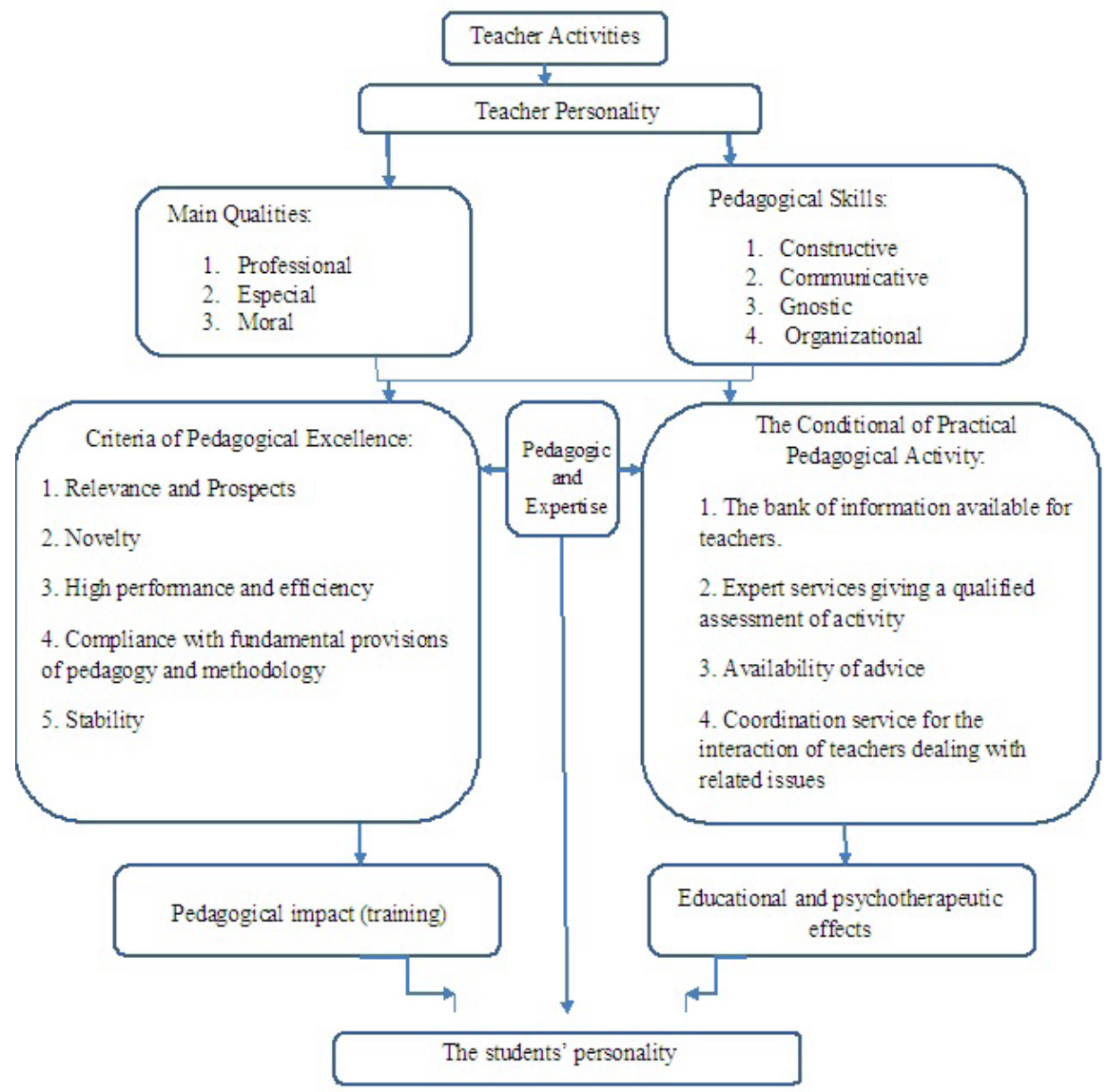

Fig. 1. The model of formation of pedagogical skill of the teacher in the course of their activities (Own elaboration, 2020). 


\section{Conclusion}

The methodological work of a professional educational institution acts as a system that controls the growth of the professional skills of a pedagogical worker, and is implemented through external management directly from the leadership and methodological service of a professional educational institution, mentors and educational organizations and management by the engineering and pedagogical worker himself. The following organizational and pedagogical conditions for practical methodological work have been created with the introduction of innovative teaching methods and technologies for the formation and development of teachers' creativity in professional educational institutions: the creation of an information bank accessible for teachers; the creation of a system of expert services that makes it possible to obtain a qualified assessment of a certain activity; organization of advisory assistance; the organization of a coordination center, providing both the interaction of teachers involved in related problems, and the relationship of teaching practice with modern scientific research of a professional educational institution. Today not only need the teachers to be informed about new pedagogical technologies, but also there is the pressing need for a system of scientific and methodological assistance for a personality-oriented choice of a teacher to be created.

One of the forms of organizing such assistance to teachers is the School of Pedagogical Excellence, in which a teacher of the highest category broadcasts the accumulated experience of studying and introducing new technologies into practice. The purpose of the "School of Pedagogical Excellence" is not only to tell, but also to show how this is done. The first part is theoretical and reveals the basics of pedagogical technology, the second is practical, the master teacher invites colleagues to his lesson, where he practices the most complex elements of the methodology, techniques and stages of pedagogical technology. The basic principle of constructing such a form of methodological work is comfort for each teacher, the ability to see the perspective of their development, and the creation of an atmosphere of creativity.

The result is the formation of professional competence, i.e. the formation of professional competence, depends on the work of the methodologist, also it depends on the ability of the teacher to manage the activities which in this case equals to the level of skill that a teacher achieves in the course of his professional activity. 
E.V. Yakovleva, A.V. Denisenko, E.F. Shaleeva, S.I. Artemyeva, N.P. Rodinova, V.M. Ostroukhov y M.S. Kalney

\section{Bibliographic References}

BADAKHOVA, Inna Tatiana. 2017. "Formation of professionally significant qualities of future managers in the training process forming" In: Modern Scientist. Issue No 7, pp. 81-84.

BAGAEVA, Iriana Demitry. 1991 Professionalism of pedagogical activity and the foundations of its formation in the future teacher: Ust-Kamenogorsk, p. 338 .

BOGOYAVLENSKAYA, Demitry Barbara. 1981. Path to creativity. M.: Rational organization of the educational activities.-Moscow. Znanie, p. 96.

BORISOVA, Mikaeil Valery. 2018. "Musokhranov A.Yu., Sidorova N.A. Use of fitness directions elements on physical education classes and their psychomatic impact on students of the special medical group" In: Modern Scientist. Issue No. 1, pp. 6-9.

BOROVIKOVA, Tatiana Vlademir. 2017. "Methodological bases of formation of the intellectual potential of territories in the conditions of innovative economy” In: Modern Economy Success. Issue No. 6, pp. 46-49.

BUKHVALOV, Volkano Antoni. 1993. Algorithms of pedagogical creativity: M.: Prosveshenie, p. 96.

GADZAOV, Antoni Fabio; DZERZHINSKAYA, M.R. 2018. "Mathematical methods of analysis of the periodic components of economic processes" In: Modern Economy Success. Issue No. 1, pp. 14-18.

GASANOVA, Pavel George; DAUDOVA, D.M; KABIEVA, R.A; TSAHAEVA, A.A. 2017. "Moral qualities of businessmen in public con-sciousness" In: Modern Scientist. Vol. 1. Issue No. 1, pp. 209-211.

GNATYUK, Samuel Natalia; PEKERT, N.A. 2018. "Education as a factor of sustainable development of agriculture" In: Russian Economic Bulletin. Vol. 1. Issue No.3, pp. 18-27.

KAN-KALIK, Vlademir Andreevna. 1981. Pedagogical activity as a creative process: Dis dr ped. sciences. NIIVPSH. Moscow, Russia, p. 430.

KAN-KALIK, Valerian Albina. 1990. Pedagogical creativity: Pedagogika, p. 144.

KHOZYAINOV, Gulnura Iriana. 1988. Teacher Mastery: A Toolkit. - M.: Higher School, p. 168. 
KUZNETSOV, Antoni Albina; IGNATYEVA, T.A; KUZNETSOV, A.O. 2018. "Strategy and key elements of competitiveness" In: Modern Economy Success. Issue No. 1, pp. 25-29.

NARKEVICH, Lyudmila Valery; NARKEVICH, E.A. 2018. "Financial condition analysis in the crisis management system" In: Russian Economic Bulletin. Vol. 1. Issue No. 4, pp.10-24.

PIONOVA, Rustem Svetlana. 2002. Pedagogy of higher education. Minsk Universitetskoye. Minsk, Belarus p. 256.

PONOMAREV, Yuryevna Angelina. 1976. Psychology of creativity. Nauka. Moscow, Russia, p. 303.

ROGINSKY V.M, Azbuka. 1990. (ABC) of pedagogical work. Higher School, Moscow, Russia, p. 112.

SERGEEVA, Marshal George. 2015. The development of pedagogical skills of a teacher in modern conditions: Monograph, NOU VPO MIL. Moscow, Russia, p. 180.

SERGEEVA, Mikael Gulnur; TRUBAKOVA, D.I. 2017. "Teacher's Reflection Formation as Factor of Effectiveness Children's Social Intelligence Forming” In: Modern Scientist. Issue No. 7, pp. 62-64.

SHCHURKOVA, Natalia Elena. 1998. Workshop on pedagogical technology. M. Pedagogical Society of Russia, p. 250.

SHTYKOVA, Lara Antoni. 2001. Organization of innovative activity in a general educational institution. Author's summary;. Cand. ped sciences. Izhevsk, Moscow, Russia. p. 16.

STOLYARENKO, Andreevna Munirovich. 2001. Psychology and Pedagogy: A Textbook for High Schools. - M.: UNITY-DANA. Moscow, Russia. p. 423.

YAKOVLEVA, Natalia Lyudmila. 1991. Preparing students for creative educational activities. - Chelyabinsk: publishing house of the ChSPI Moscow, Russia. p. 128.

ZAGVYAZINSKY, Valery PETROVA. 1987. Pedagogical creativity of a teacher: Pedagogika, p.199. 

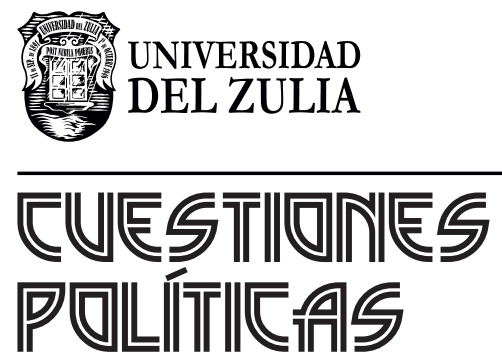

Vol. $37 \mathrm{~N}^{\circ} 64$

Esta revista fue editada en formato digital y publicada en junio de 2020, por el Fondo Editorial Serbiluz, Universidad del Zulia. Maracaibo-Venezuela 